\title{
Semi-rigid penile prosthesis as a salvage management of idiopathic ischemic stuttering priapism
}

This article was published in the following Dove Press journal:

Research and Reports in Urology

4 September 2015

Number of times this article has been viewed

\section{Amr A Faddan \\ Alexey $\vee$ Aksenov \\ Carsten M Naumann \\ Klaus $P$ Jünemann \\ Daniar K Osmonov}

Department of Urology and Pediatric Urology, University Hospital Schleswig-Holstein, Kiel, Germany
Correspondence: Amr A Faddan Department of Urology and Pediatric Urology, University Hospital SchleswigHolstein, Campus Kiel, Arnold-HellerStr 3, Haus I8 D - 24I05 Kiel, Germany Tel +49 43I 597 44II

Email amr.faddan123@gmail.com
Introduction: Priapism is the persistent erection resulting from dysfunction of the mechanisms that regulate penile swelling, stiffness, and sagging. It is a full or partial erection that persists for a period more than 4 hours beyond sexual stimulation and/or orgasm or is unrelated to sexual stimulation. Ischemic priapism should be managed in a step-by-step fashion.

Objective: To demonstrate step-by-step management of stuttering refractory ischemic priapism. We report a case of stuttering refractory ischemic priapism. Moreover, we reviewed different approaches to priapism management in the literature.

Case presentation: A 53-year-old male presented with a painful erection of 29 hours' duration, probably caused by consumption of alcohol. The penile blood gas showed a $\mathrm{pH}$ of 7.08, $\mathrm{PCO}_{2}$ of $75 \mathrm{mmHg}$ and $\mathrm{PO}_{2}$ of $39 \mathrm{mmHg}$. Aspiration was followed by irrigation of an $\alpha$-adrenergic, Winter and T-shunt operations were preformed, and finally a semi-rigid penile prosthesis was implanted to overcome the refractory stuttering ischemic priapism.

Conclusion: In case of stuttering refractory ischemic priapism, immediate implantation of a penile prosthesis is a simple and effective procedure that manages both the acute episode and the inevitable erectile dysfunction that would otherwise occur, while preserving penile length.

Keywords: priapism, stuttering priapism, shunting operation, penile prosthesis

\section{Introduction}

While relatively rare, priapism is a medical emergency. Although not all forms of priapism need immediate intervention, ischemic priapism is linked to progressive fibrosis of the cavernosal tissue and erectile dysfunction. ${ }^{1,2}$ Priapism is a persistent erection resulting from a dysfunction of the mechanisms that regulate penile swelling, stiffness, and sagging. It is a full or partial erection that continues more than 4 hours beyond sexual stimulation and/or orgasm or is unrelated to sexual stimulation. ${ }^{3}$ Current data show that the occurrence of priapism in the general population is low ( $0.5-0.9$ cases per 100,000 person-years) ${ }^{4}$

Ischemic (veno-occlusive, low flow) priapism is the most frequent form of priapism accounting for $>95 \%$ of all priapism episodes. ${ }^{5,6}$ It is a persistent erection marked by rigidity of the corpora cavernosa and little or no cavernous arterial inflow. ${ }^{7}$ The exact time point at which irreversible damage to the corpus cavernosum smooth muscle occurs is unknown and may vary depending on the etiology of ischemic priapism and the extent of preexisting smooth muscle dysfunction. There is evidence, however, that even after only 6 hours of ischemia, irreversible changes have already taken place. ${ }^{8-10}$ In ischemic priapism, there are time-dependent changes in the corporal metabolism environment with progressive hypoxemia, hypercapnia, and acidosis. Cavernosal blood 
gas in men with ischemic priapism typically shows a $\mathrm{PO}_{2}$ of $<30 \mathrm{mmHg}$, a $\mathrm{PCO}_{2}$ of $>60 \mathrm{mmHg}$, and a $\mathrm{pH}$ of $<7.25$. $^{3}$ Stuttering priapism (intermittent) is a chronic form of ischemic priapism where repeated painful erections occur with intermittent periods of detumescence. ${ }^{3}$ The frequency and/or length of these painful priapic episodes may increase. One single episode can sometimes develop into a serious period of ischemia. ${ }^{11}$

Management of ischemic priapism depends on the cause and duration of the priapism episodes. Ischemic priapism should be managed in a step-by-step fashion. The goal is to restore penile sagging, to relieve pain, and to prevent chronic damage to the corpus cavernosum. ${ }^{3}$ The stepwise management of priapism includes first aid measures (eg, ice packs, cold baths, ejaculation, and cold water enemas), oral sympathomimetic drugs, aspiration with or without $\alpha$-adrenergic injection or irrigation, operative intervention (distal or proximal shunt), and, as the ultimate treatment option, immediate penile prosthesis implantation. In this case, we demonstrate this stepwise management of stuttering refractory ischemic priapism.

\section{Case presentation}

A 53-year-old male presented at the emergency department with persistent painful (5/10) morning erection of approximately 29 hours' duration. On the previous night, he drank a bottle of whisky and two glasses of beer, so it has been suggested that alcohol is the cause of his condition. He denied recent sexual activity, respective arousal or the intake of phosphodiesterase inhibitors. There was no history of sickle cell trait or anemia, malignancy, perineal trauma, intra-cavernous vasoactive drug injection, or illicit drug abuse. The latter was confirmed by negative toxicology screening. There was no relevant medical or psychiatric history. The patient is a smoker with a smoking index of 1,200 cigarettes, and a habit of drinking alcohol over 40 years. He reported one attack of 5 -hour priapism approximately 5 years prior. The erection occurred spontaneously that time without any sexual stimulation, but was probably co-induced by alcohol consumption; detumescence was achieved by first aid measures.

Clinical examination revealed a fully erect uncircumcised phallus, slightly edematous with moderate tenderness throughout. The corpora was fully rigid and tender, but the glans penis was soft. There was no associated erythema or induration. The remaining genitourinary examination was unremarkable. Complete blood count with differential, reticulocyte count, and hemoglobin electrophoresis were normal. The penile blood gas showed $\mathrm{pH}$ of 7.08, $\mathrm{PCO}_{2}$ of $75 \mathrm{mmHg}$, and $\mathrm{PO}_{2}$ of $39 \mathrm{mmHg}$.

The patient was initially treated with corporal blood aspiration (350 cc dark bloods) and injection of ephedrine via 21-gauge pore needle at 3 and 9 o'clock of the corpus cavernosum. This resulted in gradual detumescence and pain relief. After 20 minutes of observation, the erection relapsed. Blood gas analysis was performed, which revealed renewed ischemic priapism. Subsequently the so-called "Winter operation" was performed. This was done inserting a 21-gauge needle through the glans into the corpus cavernosum for aspiration of the blood and performance of a distal shunt between the corpus cavernosum and the corpus spongiosum. ${ }^{12}$ However, the erection quickly recurred.

A T-shunt using 12-mm Brook's dilators (Figure 1) was done, but the erection recurred again after 2 hours (Figure 2). ${ }^{13}$ As salvage management of the recurrent refractory priapism, implantation of a semi-rigid penile prosthesis was performed (Figures 3 and 4). Ethical approval was not required for this study because it was an emergency case.

\section{Discussion}

A complete medical history of each case forms the cornerstone of priapism diagnosis. This helps to identify the underlying type of priapism. Ischemic priapism can be suspected if the patient has progressive penile pain that increases with the duration of the erection. This type of priapism is also suspected if the patient has used a known drug associated with priapism, if he has sickle cell disease or another blood dyscrasia, or if he has a known neurological condition. Stuttering priapism is usually associated with repeated episodes of prolonged erections and/or generally

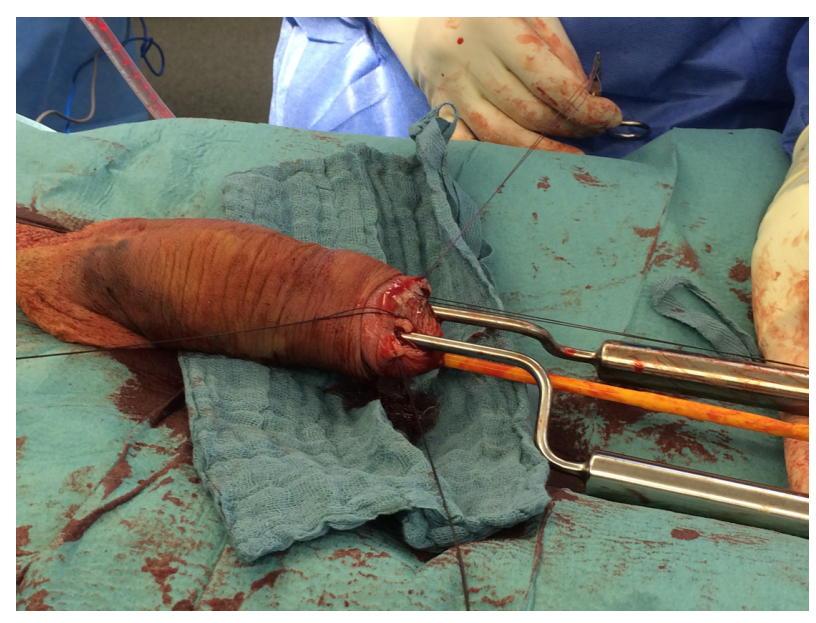

Figure I T-shunt operation with dilatation using I2-mm Brook's dilators. 


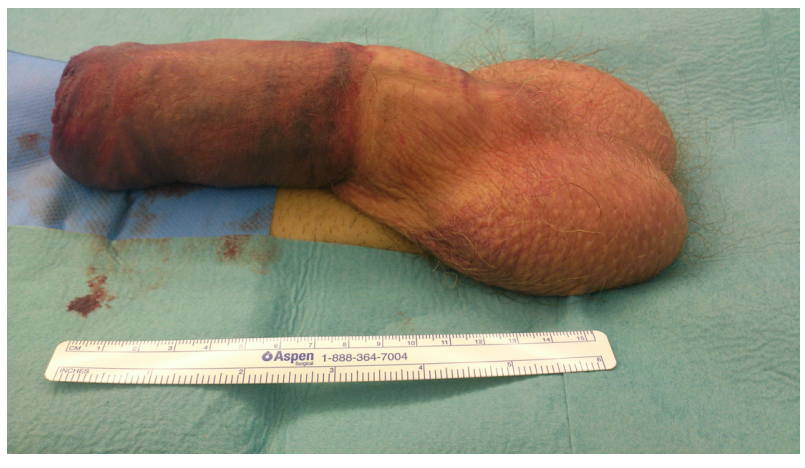

Figure 2 Edematous and erect penis after T-shunt operation.

unresolved morning erections. ${ }^{7}$ Our patient had prolonged non-resolving morning erections with progressive penile pain increasing over time.

Physical examination of the genitalia, perineum, and abdomen should be included in the diagnostic assessment of priapism. ${ }^{5,14}$ It is recommended to inspect and palpate the penis in order to ascertain the extent and degree of tumescence and rigidity. Genital exam should also focus on the degree of involvement of the cavernous bodies, the presence of local tenderness, and any evidence of trauma to the perineum. ${ }^{7}$ In ischemic priapism, the corpora is fully rigid and tender, but the glans is soft. ${ }^{11}$ Clinical evaluation of our patient showed completely rigid and tender corpora with soft glans penis.

Blood gas tests and color duplex ultrasound examinations are mostly reliable disease-identifying tools in priapism patients. In ischemic priapism, aspirated corporal blood is generally dark in color, $\mathrm{PO}_{2}=30 \mathrm{mmHg}, \mathrm{PCO}_{2}=60 \mathrm{mmHg}$, and $\mathrm{pH}=7.25$. Color duplex ultrasound could be used as a further option for cavernosal blood gas sampling. ${ }^{3}$ Penile and perineal color duplex ultrasound is recommended for evaluation of non-ischemic priapism, as it detects approximately $70 \%$ of these cases. In addition, it helps to distinguish

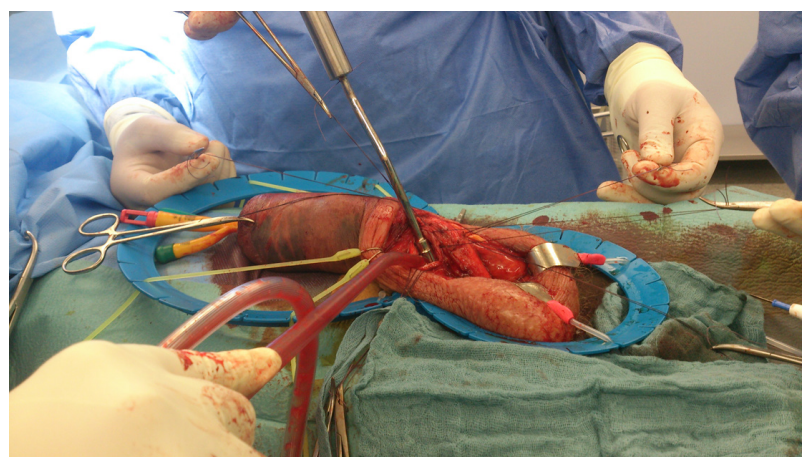

Figure 3 Penoscrotal approach for semi-rigid penile prosthesis with proximal dilatation using Rossello dilators.

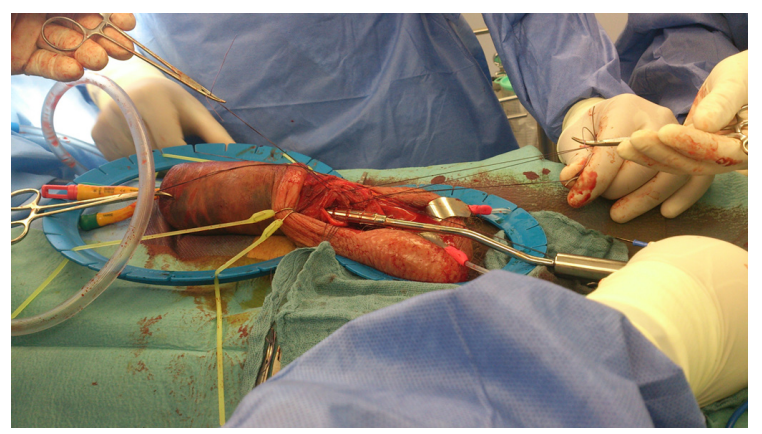

Figure 4 Penoscrotal approach for semi-rigid penile prosthesis implantation with distal dilatation using Rossello dilators.

non-ischemic from ischemic priapism as an alternative or complementary examination to blood gas analysis. ${ }^{11} \mathrm{We}$ reached the diagnosis through the history as given by the patient, genital examination, laboratory tests, and penile blood gas analysis.

Conservative management of priapism has been reported. These measures include exercise, ejaculation, ice packs, cold baths, placement of a urethral catheter, and cold water enemas. ${ }^{5}$ Other conservative measures such as oral sympathomimetic drugs have also been reported to effectively reverse prolonged erections ( $<4$ hours). This is initiated by the intracavernous injection therapies with success rates of $28 \%$ $36 \%{ }^{13}$ However, oral systemic therapy is not recommended in ischemic priapism according to the American Urological Association guidelines. Therefore, with a 29 -hour prolonged erection, this line of treatment was not appropriate.

Initial intervention may consist of therapeutic aspiration with or without irrigation, or intra-cavernous injections of sympathomimetic agents. Aspiration can instantly soften the erection and ease the pain and can even alleviate priapism in $36 \%$ of the cases. If corporal aspiration fails in case of lowflow priapism, it should be followed by $\alpha$-adrenergic injection or irrigation. ${ }^{3}$ Our patient was treated firstly by corporal blood aspiration followed by an injection of phenylephrine $(200 \mu \mathrm{g} / \mathrm{mL}$ in saline), which was administered intermittently every 10 minutes as $0.5 \mathrm{~mL}$ to $1.0 \mathrm{~mL}$ doses, up to a maximum dosage of $1 \mathrm{mg}$. After 20 minutes of observation, the erection relapsed.

Consequently, "Winter operation" was carried out but the erection returned shortly after the operation, and did not respond to local management, and the blood gas analysis showed ischemic priapism. Therefore, we performed the recently described technique of a bilateral T-shaped distal shunt between the corpus cavernosum and the glans penis with proximal and distal dilatation using Brook's dilators. ${ }^{13}$ 
As the erection recurred again and the total duration of the erection was approximately 96 hours with a high risk of erectile dysfunction and penile deformity, we decided against the proximal shunt operations which are associated with high incidence of erectile dysfunction. Therefore, we discussed with the patient the implantation of semi-rigid penile prosthesis as the final solution for this condition.

Open proximal shunting procedures of the corpus cavernosum to the spongiosum require a trans-scrotal or trans-perineal approach, either unilateral "Quackles” or bilateral "Sacher", 15 to saphenous vein "Grayhack shunt", or deep dorsal vein "Barry shunt". ${ }^{7}$ It is unrealistic to predict whether one technique is more successful than another because of the restricted available information, specifically the absence of information that might allow for a reliable forecast of results. ${ }^{11}$ These procedures are time consuming, and difficult to perform, and the reporting of serious adverse events includes urethral fistulas and abscesses and cavernositis following the Quackels shunt, ${ }^{16}$ and pulmonary embolism following the Grayhack procedure. ${ }^{17}$ These approaches were reported with success rates of $77 \%$, but with a subsequent $50 \%$ prevalence of erectile dysfunction. ${ }^{18}$

Intractable acute ischemic priapism or priapism episodes lasting 48-72 hours usually result in complete impairment of erectile function, along with the risk of significant penile deformity. In such cases, immediate penile prosthesis implantation has been recommended as it seems to avoid surgical difficulties and potential complications (eg, urethral injury, tunical erosion, infection, and/or penile shortening) that may occur if surgery is performed at a later time and after corporal fibrosis has already developed. ${ }^{19-21}$ Some centers propose immediate implantation of the semi-rigid penile prosthesis in acute ischemic priapism management if sympathomimetic intra-cavernous treatments and shunting operations have failed. ${ }^{22}$ However, it is not clear exactly at which point prosthesis implantation becomes a reasonable option for the management of ischemic priapism. ${ }^{7}$

The advantages of immediate implantation lie in the circumstance that corporal fibrosis has not yet set in, as well as in the chance to preserve penile length and to prevent penile deformity; moreover it is technically easier. ${ }^{20}$ On the other hand, it is associated with a high risk of infection and distal erosion, especially if the patient was previously treated with distal shunt operations, ${ }^{20}$ as was the case with our patient who underwent Winter and T-shunt operations. Due to the high risk of infection, we chose a semi-rigid penile prosthesis for implantation. Early insertion of a penile prosthesis manages the priapism episode, enables the return of sexual activity, reliably maintains penile length, and results in a high satisfaction rate..$^{23-25}$ The selection of an adequate type of penile prosthesis for immediate implantation is a subject for discussion. Implantation of a semi-rigid penile prosthesis offers some benefits, such as shorter surgical time, lower risk of infection, and prevention of fibrotic shortening or curvature of the penis, but it is associated with a higher risk of distal erosion than the inflatable prosthesis. ${ }^{20,26}$

\section{Conclusion}

We report a case of refractory ischemic priapism which did not respond to the distal shunting operation. Such cases are ideally treated by a semi-rigid penile prosthesis. Immediate insertion of a penile prosthesis is a simple and effective procedure that manages both the acute episode as well as the inevitable erectile dysfunction that would otherwise occur, while preserving penile length. The patients should also be offered the inflatable penile prosthesis, but this could be postponed until after the initial insertion of a semi-rigid device as a temporary measure, as it helps to maintain penile length and shape and it makes it easier to insert an inflatable device at a later point. ${ }^{20}$

\section{Acknowledgment}

We would like to pay special thankfulness, warmth, and appreciation to all staff members in Urology department, Assuit University Hospital, Egypt, for their encouragement and support.

\section{Disclosure}

The authors report no conflicts of interest in this work.

\section{References}

1. El-Bahnasawy MS, Dawood A, Farouk A. Low-flow priapism: risk factors for erectile dysfunction. BJU Int. 2002;89(3):285-290.

2. Spycher MA, Hauri D. The ultrastructure of the erectile tissue in priapism. J Urol. 1986;135(1):142-147.

3. Montague DK, Jarow J, Broderick GA, et al. American Urological Association guideline on the management of priapism. JUrol. 2003;170(4 Pt 1): $1318-1324$.

4. Eland IA, van der Lei J, Stricker BH, Sturkenboom MJ. Incidence of priapism in the general population. Urology. 2001;57(5):970-972.

5. Broderick GA, Kadioglu A, Bivalacqua TJ, Ghanem H, Nehra A, Shamloul R. Priapism: pathogenesis, epidemiology, and management. $J$ Sex Med. 2010;7(1 Pt 2):476-500.

6. Berger R, Billups K, Brock G, et al. Report of the American Foundation for Urologic Disease (AFUD) thought leader panel for evaluation and treatment of priapism. Int J Impot Res. 2001;13 Suppl 5: S39-S43.

7. Campbell MF, Wein AJ, Kavoussi LR. Campbell-Walsh Urology. 10th ed. Philadelphia: Saunders/Elsevier; 2012:760-780.

8. Kulmala RV, Tamella TL. Effects of priapism lasting 24 hours or longer caused by intracavernosal injection of vasoactive drugs. Int J Impot Res. 1995;7(2):131-136. 
9. Broderick GA, Gordon D, Hypolite J, Levin RM. Anoxia and corporal smooth muscle dysfunction: a model for ischemic priapism. $J$ Urol. 1994;151(1):259-262.

10. Juenemann KP, Lue TF, Abozeid M, Hellstrom WJ, Tanagho EA Blood gas analysis in drug-induced penile erection. Urol Int. 1986; 41(3):207-211.

11. Salonia A, Eardley I, Giuliano F, et al. European Association of Urology Guidelines on Priapism. Eur Urol. 2014;65(2):480-489.

12. Winter CC. Cure of idiopathic priapism: new procedure of creating fistula between glans penis and corpora cavernosa. Urology. 1976;8(4): 389-391.

13. Brant WO, Garcia MM, Bella AJ, Chi T, Lue TF. T-shaped shunt and intracavernous tunneling for prolonged ischemic priapism. J Urol. 2009;181(4):1699-1705.

14. Burnett AL, Bivalacqua TJ. Priapism: new concepts in medical and surgical management. Urol Clin North Am. 2011;38(2):185-194.

15. Carter RG, Thomas CE, Tomskey GC. Cavernospongiosum shunts in treatment of priapism. Urology. 1976;7(3):292-295.

16. Ochoa Urdangarain O, Hermida Pérez JA. [Priapism. Our experience] Priapismo. Nuestra experiencia. Arch Esp Urol. 1998;51:269-276. Spanish.

17. Kandel GL, Bender LI, Grove JS. Pulmonary embolism: a complication of corpus-saphenous shunt for priapism. J Urol. 1968;99(2):196-197.

18. Huang Y, Harraz AM, Shindel AW, Lue TF. Evaluation and management of priapism: 2009 update. Nat Rev Urol. 2009;6(5):262-271.
19. Upadhyay J, Shekarriz B, Dhabuwala CB. Penile implant for intractable priapism associated with sickle cell disease. Urology. 1998;51(4): 638-639.

20. Ralph DJ, Garaffa G, Muneer A, et al. The immediate insertion of a penile prosthesis for acute ischaemic priapism. Eur Urol. 2009;56(6): 1033-1038.

21. Salem EA, El Aasser O. Management of ischemic priapism by penile prosthesis insertion: prevention of distal erosion. J Urol. 2010;183(6): 2300-2303.

22. Rees RW, Kalsi J, Minhas S, Peters J, Kell P, Ralph DJ. The management of low-flow priapism with the immediate insertion of a penile prosthesis. BJU Int. 2002;90(9):893-897.

23. Pryor J, Akkus E, Alter G, et al. Priapism. J Sex Med. 2004;1(1): 116-120.

24. Sundaram CP, Fernandes ET, Ercole C, Billups KL. Management of refractory priapism with penile prostheses. Br J Urol. 1997; 79(4):659.

25. Minervini A, Ralph DJ, Pryor JP. Outcome of penile prosthesis implantation for treating erectile dysfunction: experience with 504 procedures. BJU Int. 2006;97(1):129-133.

26. Sedigh O, Rolle L, Negro C, et al. Early insertion of inflatable penile prosthesis for intractable ischemic priapism: our experience and review of the literature. Urology. 2011;23(4):158-164.
Research and Reports in Urology

\section{Publish your work in this journal}

Research and Reports in Urology is an international, peer-reviewed, open access journal publishing original research, reports, editorials, reviews and commentaries on all aspects of adult and pediatric urology in the clinic and laboratory including the following topics: Pathology, pathophysiology of urological disease; Investigation and treatment of

\section{Dovepress}

urological disease; Pharmacology of drugs used for the treatment of urological disease. The manuscript management system is completely online and includes a very quick and fair peer-review system, which is all easy to use. Visit http://www.dovepress.com/testimonials.php to read real quotes from published authors. 